\title{
POPULAR LECTURE,
}

By Sir CHARLES A. CAMERON, Professor of Chemistry and Hygiene, R.C.S.I., and Superintendent Medical Officer of Health, Dublin.

The Maror or Newcastee in the Chair. Delivered Septemlier 8th, 1896.

\section{WHY, WHAT, AND WHEN WE EAT.}

\section{ABSTRACT.}

The lecturer after some preliminary observations in the course of which he referred to his having been present at the first Congress held by the Institute, and having presided at its Portsmouth Congress, said that he would endeavour to explain with the use of as few technical terms as possible, what food was composed of, why we used it, and what were the best times to consume it. The world was, so far as we knew, composed of about seventy elements, or simple bodies. They constituted the raw materials so to speak, with which nature built up all its rich and varied structures. The billowy ocean, the atmosphere, the vast mountain chains, the spreading fields of emerald green, the forests with their almost infinite variety of vegetable life, the nearly innumerable forms of animals, the solid crust of the earth, in a word the great globe and all which it inherits may be resolved into these few elements. What was an element? Any substance which resisted every attempt to extract from it something different from itself. For example, from chalk, two distinct bodies could be extracted, namely lime and a gas termed carbonic acid. From lime, a brilliant metal, calcium, and a gas termed oxygen could be obtained, whilst carbonic acid yielded carbon or charcoal, and oxygen gas. No one has yet extracted other bodies from calcium, carbon and oxygen, and they are therefore, at present at least, regarded as elements. Very many of the elements occurred in insignificant quantities and in very rare minerals, whilst on the other hand, the objects of everyday life, such as animals and plants, soils, ordinary rocks, air and water, were composed of little more than a dozen of the elements. Oxygen alone made up about half the weight of the surface of the globe, and probably of its interior. Disregarding traces of a few elements, animals and plants were composed of oxygen, hydrogen, carbon, nitrogen, phosphorus, sulphur, calcium, magnesium, potassium, sodium and iron. In the mineral kingdom these elements existed, in combination with each other forming water, carbonic acid, ammonia, and saline and earthy matters. It was the function of plants to organize these inert lifeless matters into vegetable structures, such as starch, sugar, 
gum, wood, albumen, and various other matters, of which some were used as food by animals. The lecturer explained at consiclerable Jength, how it was that the mineral bodies were converted into organic substances. Matter was indestructible, but its form admitted of protean changes. So also was it the case with the forces of nature,-heat, light, magnetism, and heat could be converted into electricity, electricity into mignetism. The great orb of clay was the sonrce of all the force or energy which operated upon earthy matter. The plant was a mere though most wondrous mechanism. It no more originated energy or force, than a steam engine, minus fuel, did. It however absorbed from the Solar beams the energy with which it decomposed water, carbonic acid, ammonia and other minerals, and recombining their elements, produced organic matter. The energy used by the plants for this purpose was not, could not, be annihilated or lost, - it remained stored up in a latent or hidden form in the vegrable matter. If the vegetable matter were converted into mineral matter, the latent energy would re-appear in some form or forms. Supposing the vegetable matter were burned in a furnace, the energy would appear as leat and light. If it were used as food by an animal, it would also be converted into mineral matter, with simultaneous evolution of heat and motive power. In the conversion of carbonic acid and water into vegetable matter, a large portion of the oxygen which these compounds contain is evolved into the air in a free state. The oxygen thus set free is capable of combining with the substances from which the plant ejected it, and of reproducing carbonic acid and water. Whenever it does this it sets free the energy which the plant had used to decompose the water and carbonic acid. A man requires to have a temperature of $98.6^{\circ} \mathrm{F}$., and force is necessary to maintain the beating of his heart, his respiration and other vital functions, and to enable him to move about and perform work. 'The force stored up in his food supplies this heat and energy, becoming at the same time converted into mineral matter. Plants absorb carbonic acid and evolve oxygen ; animals absorb oxygen and expire carbonic acid: the former organize, the latter disorganize. The food is used to repair the waste of the body, for it is chiefly the body that burns away, evolving heat and motion. This is the philosophy of food. The best kinds develop the most heat and energy, and if flavour be good are the dearest aliments.

Sir Charles next described the classification of food. The most abundant were the carbohydrates, which were composed of only three elements, oxygen, hydrogen, and carbon, the two former in the proportions. in which they form water. The starches and 
sugars were the chjef carbohydroles. They formed fats in the body, $2 \frac{1}{2}$ lbs. of carbohydrate producing $1 \mathrm{lb}$. of fat. The sugars wore the natural food of the young, and their instinctive longing for them should be gratified. It was nonsense to say that sugar destroyed the tecth. Fats were composed of the same elements as the carbolyclrates, only they contained more hydrogen and carbon and much less oxygen. They constituted a very raluable portion of our food, and their absence from a diet was a great defect. They evolved much heat and energy by their combustion in the body. The third great class of foods were the albumenoids, which in addition to the elements present in carbohydrates, contained nitrogen, plosplorus, and sulphur, and were always associated with small quantities of earthy and saline matters. Formerly, their importance was overestimated, but still they are indispensable to life, and a man requires at least $4 \mathrm{ozs}$. of them daily to keep him alive. A hardworking man will require nearly $\frac{1}{3} \mathrm{lb}$. of albumen, rather more than $\frac{1}{3} \mathrm{lb}$. fat, and nearly $1 \mathrm{lb}$. of carbohydrates. If he takes less fat, he requires more carbohydrates and vice versit. $1 \frac{3}{4} \mathrm{lbs}$. of wheat flour contain sufficient albuminous matter for a man, but not sufficient fat or carbohydrates, to supply which about $2 \mathrm{lbs}$. are required. $1 \frac{1}{\mathrm{~g}} \mathrm{lbs}$. of peas supply sufficient nitrogenons matter, but 2 lbs. are required for carbon. A diet of peas would therefore be wasteful. A mixed diet is the best, and the structure of man's teeth and digestive organs showed that he was omnivorous. Much information was given as regards purity of not only food but air, for nearly $\frac{1}{4}$ cwt. of the latter. was daily taken in the body. The process of digestion was briefly explained, thorough mastication was essential, as it enabled thie food to be more easily clissolved in the stomach. The lecturer descanted for some time on the importance of attending to the condition of the teeth in the case of children, and urged those who had lost their teeth to provide themselves with artificial ones. The ptyaline or nitrogenous ferment in the salira converted starch into sugar. In the stomach the food was churned up and mixed with a nitrogenous ferment termed pepsin, which macle the nitrogenous food (proteids) into soluble bodies or peptones. In the duodenum or lower stomach fats and starch were made soluble by the action of pancreatin, another nitrogenous ferment. After these changes the food became a milllike liquid which passed into the blood and became assimilated. Regularity of time of eating was of great importance, as nature was orderly and periodicity was one of its prime laws.

The subject of the cooking of food was next cliscussed. If we wanted soup, meat should be put into cold water and slowly heated, delaying the process of boiling as long as possible. In 
this way all the soluble matters pass into the water, because the sudden application of boiling water has not coagulated and rendered the albumen insoluble. If we want meat, not soup, then we should plunge the raw meat into boiling water, and so congulate its albumen and prevent it from dissolving in the water. Too much attention could not be bestowed upon the cooking of food, and reasons were given why the process renclered food more digestible, as, for example, by bursting of starch granules and liberating the soft starch from its very hard envelopes. The best time to take food was early in the day, at which time the vital functions and power of assimilation were at the maxima. Late meals were not as a rule so well digested as early ones. He did not believe in a man working hard for several hours before breakfast.

The subject of obesity was treated upon partly in a humorous manner. The beanty of woman was partly due to a layer of fat below the skin, which gave her the beautiful curves and softness of outline which were so much admired. As youth declined, fat usually increased, and gave that soft and comely appearance to many women who at mature age were handsomer than in their scraggy youth. It however sometimes lappened that obesity became so excessive as to become an actual disease. When a man was obliged to sit on two chairs, to have to go downstairs backwards and to be umable to enter a cab, fat certainly became a great infliction. To prevent undue accumulation of fat nothing was so efficacious as exercise; the more exercise a man took the more fat he consumed. Who ever saw a fat professional pedestrian? Letter carriers and lamp lighters were rarely fat; the advantages of open-air exercises were not confined to fat persons-fat or lean people were improved in health and strength by them. The games in which ladies were now adepts, such as, for example, tennis, were great hygienic agencies. They induced the ladies to stay out in the pure fresh air by which their blood was thoroughly arterialized and purified, whilst their exercise developed their muscles. He almost thought that they were becoming taller and stronger than they were in the days of his youth, and they might ultimately progress into the remarkably tall and athletic women so graphically described by Bulwer Lytton in his "Coming Race." The lecture was illustrated by several experiments, one of which showed how people appeared when they ate too much and took no exercise, the lecturer remarking that the Mayor's face had lost its rosy lue and the Sheriff's face had become green. Votes of thanks to the lecturer and the clatirman brought the proceedings to a close. 


\section{CONGRESS \& EXHIBITION AT NEWCASTLE- UPON-TYNE.}

The Fifteenth Congress and Exhibition of the Institute was held at Newcastle-upon-Tyne, from September 2nd to 9th, by invitation of the Mayor and Corporation. This is the second time that the Institute has visited this city, the previous meeting being in the year 1882 .

Very suitable accommodation was provided for the meetings of the Congress in the University of Durham College of Medicine, the Durham College of Science, and the meeting room of the Presbyterian Church.

The Congress was received by the Mayor (Mr. Riler Lord), and his speech of welcome was responded to by H.R.H. the Duke of Cambridge (Presilent) on behalf of the Institute, by the Right Honourable Earl Percy (President of the Congress) on behalf of the Congress, and by the Mayor of Southampton (Mr. M. Emanuel) on behalf of the delegates from the various Sanitary Authorities.

A Public Luncheon was held at the Assembly Rooms, at which the Mayor presided, and the following toasts were proposed :-

The Queen, by The Chairman.

The Prince and Princess of Wales, The Dutie of Cambridlige, and other members of the Royal Family, by the Chairman.

Responded to by H.R.H. The Duke of Cambridge.

The Sanitary Institute and Congress, by Mr. Alderman Newton, Chairman of the Sanitary Committee.

Responded to by Mr. A. Wynter Blyth, Chairman of Council.

The Mayor and Corporation of Nezucastle-upon-Tyne, by Sir Douglas Galton.

Responded to by the Right Worshipful the Mayor and the Sheriff.

His Royal Highness afterwards formally opened the Exhibition, which was held in Olympia and the adjoining drill ground of the Northumberland Hussars, the ground having been kindly placed at the disposal of the Institute for this purpose. The Exhibition remained open until September 26 th, and was visited by 51,000 people. A list of the Awards made by the judges will be found on page 343 .

The first General Meeting was held in the erening of September 2nd. H.R.H. the Duke of Cambridge as President of the Institute, installed Earl Percy as President of the Congress. His Lordship then delivered the Inaugural Address. A letter was received from Sir Francis Powell, saying :

"I write one line to express my great regret that my arrangements for the autumn have placed it beyond my power to attend 
the Conference at Newcastle, and formally surrender the Chair to my successor. I congratulate the Congress on having secured the services of Earl Percy, whose personal qualifications, $t$ s say nothing of his social position, so eminently qualify him for the Presidential Chair.

"I cannot retire without placing on record the great gratification which I feel on the passing through Parliament by the Government of the Bill under the name of 'The Public Health' Bill. That new Act abolishes Quarantine. It may be remembered that at Liverpool I strongly urged the prompt and complete carrying out of that Reform.

"Such a measure is beyond the power of any non-official nember in these days. I have, however, continually pressed both the list and the present Government, and, as the result of these exertions, can report to the Congress at the great seaport of the East Coast the amendment of the law and the destruction of an obsolete and absurd system which I advocated in the most vigorous language at my command to the Congress assembled at Liverpool.

"Wishing you a successful meeting, I remain, yours faithfully."

The business of the Congress was divided into three sections, and five Special Conferences were held. Particulars of these are given in the programme of the Congress in Part II. of the Journal. 'The Presidents' Adclresses are published in the present number of the Journal. The papers read in the Sectional Meetings with the discussions upon them will be published in Part IV. of the present volume, and an abstract of the proceedings of the Conferences will be given in Part I. of Vol. XVIII.

During the meeting excursions were made to the Elswick Works, to Warkworth and Alnwick Castles, to Cragside, Rothbury, and a garden party was given at .Jesmond Dene. Visits were also arranged to Sewage Disposal Worlss, Water Works, New Railways, Shipbuilding Yards, Sanitary-pipe Works, Filter Beds, Isolation Hospital, Flonting Hospital, and Disinfecting Hulk.

The closing meeting of the Congress was held on September 8th, the Right Honourable Earl Percy in the Chair.

Reports of the work done in the different Sections of the Congress, and the Resolutions passed, were read by the respective Secretaries, and the Resolutions were referred to the Council of the Institute for" consiclerntion.

Proposed by Earl Percy, seconded by Dr. H. E. Armstrong, and resolved :-

"That the most cordial thanks of The Sanitary Institute and Congress are due to the Mayor, the Mayoless, and the Corporation of Newcastle-upon-Tyne for the reception accorded to the meeting and for the welcome they have given to the members in the city."

VOL. XVII. PAIRT III. 
Proposed by the Chairman of the Congress Committee, Dr. J. F. J. Sykes, seconded by Dr. J. W. Hembrough :-

"That the most sincere thanks of the Congress be tendered to the President, Prof. Philipson, and the Members of Council of the University of Durham College of Medicine, the Principal, Rer. H. P. Gurney, and Council of the Durham College of Science, the Rev. Dr. Ross and the Deacons' Court of the Presbyterian Church, Colonel Cookson and the officers of the Nortbumberland Hussars, for the very suitable and convenient rooms, grounds, and the facilities accorded to the Congress, which have greatly enhanced the success of the meeting."

Proposed by the Sheriff of Newcastle, seconded by Sir Charles Cameron, and resolved:-

"That the hearty thanks of the members of the Congress be given to those who have so kindly shown hospitality, at private receptions, by privileges accorded to the members, at the various excursions, which have added so greatly to the pleasure and enjogment of the meeting."

Proposed by Mr. G. .J. Symons, scconded by Dr. H. R. Kenwood, and resolved:-

"That the earnest thanks of the Congress are due to the Local General Committee, the varions sub-committees and the Local Secretaries, for their arduous labours in their several departments, and for their unremitting exertions in carrying out the many details in the organization of the Congress which have culminated in such a successful meeting."

Proposed by Mr. Alderman Newton, seconded by Mr. E. G. Mawbey, and resolved:-

"That the thanks of this meeting are clue to the members of the Press for the full and accurate reports which bave been published of the proceedings, and which are largely instrumental in the dissemination of the teachings of the Congress."

Proposed by Dr. H. E. Armstrong, seconded by Mr. Hemry Law :-

"That this meeting clesires to ixpress to the Right Honourable Earl Percy, P.C., President of the Congress, their high appreciation of the great services that he has rendered in presiding over the merting and for all the personal interest which he has so kindly displayed in its work, and in the interest of the members attending:"

The numbers attending the Congress were as follows:Delegates, 515; Members and A ssociates of the Institute, abont 210 ; Associates of the Congress, 350 ; making a total attendance of over 1,000 .

Delegates were appointed by 203 Sanitary Authorities, and by 36 Societies and Associations. 